\title{
A Study on Corrosion Behavior of Vacuum Brazed OFE Copper Joints of Industrial Accelerator
}

\author{
R. K. Gupta*, R. S. Sandha, P. Ram Sankar, S. K. Rai, P. Ganesh, R. Kaul, Jishnu Dwivedi, B. Singh \\ Raja Ramanna Centre for Advanced Technology, Indore - 452013, India
}

Copyright $\bigcirc 2016$ by authors, all rights reserved. Authors agree that this article remains permanently open access under the terms of the Creative Commons Attribution License 4.0 International License

\begin{abstract}
The paper describes an experimental study involving investigation of corrosion possibilities in cooling circuit of an in-house developed $10 \mathrm{MeV}, 6 \mathrm{~kW}$ S-band industrial electron linear accelerator, comprising of vacuum brazed multiple OFE copper cavities. The study was performed on vacuum brazed OFE copper specimens in process water used in the cooling circuit of the accelerator structure. The results of the study has demonstrated that surface of the brazed OFE copper specimens, exposed to stagnant process water, develops passive oxide layer in the initial period of specimen's exposure. This oxide layer protects underlying substrate from further corrosion. In contrast, specimens exposed to flowing process water displays relatively higher rate of corrosion. On the basis of short term immersion tests (for 45 days) in flowing conditions the estimated rate of general corrosion was found to be about $0.18 \mathrm{mils} /$ year (equivalent to $4.5 \mu \mathrm{m} /$ year) which is quite low. However, a long term corrosion study in simulated process loop would provide more useful information regarding corrosion behaviour of the brazed joints of the accelerating structure.
\end{abstract}

Keywords Vacuum Brazed, Accelerating Structure, Corrosion, Copper

\section{Introduction}

A $10 \mathrm{MeV}, 6 \mathrm{~kW}$ S-band electron linear accelerator (linac) has been indigenously developed at Raja Ramanna Centre for Advanced Technology for industrial applications. The in-house fabricated accelerating structure is currently under continuous operation and has been tested at beam power more than $4.2 \mathrm{~kW}$. The accelerating structure of electron linac comprises of RF couplers, buncher section and regular section. Regular section has 45 accelerating cavities of similar shape [1]. Figure 1 presents longitudinal section of the accelerating structure. The accelerating structure is made of OFE copper and is fabricated by vacuum brazing of cavities and coupler components using BVAg- 8 and Palcusil-5 as braze filler metals (BFM). During accelerator operation, RF power is dissipated on cavities surface and the resultant heat is removed by circulating low conductivity water (LCW) in cooling jackets provided around the accelerating structure whose inner part is maintained under vacuum. Corrosion characteristics of OFE copper brazed joints in LCW environment is of utmost importance for satisfactory long-term operation of the industrial linac. To the best of our knowledge very limited literature [2] is available on corrosion of copper braze joints in LCW.

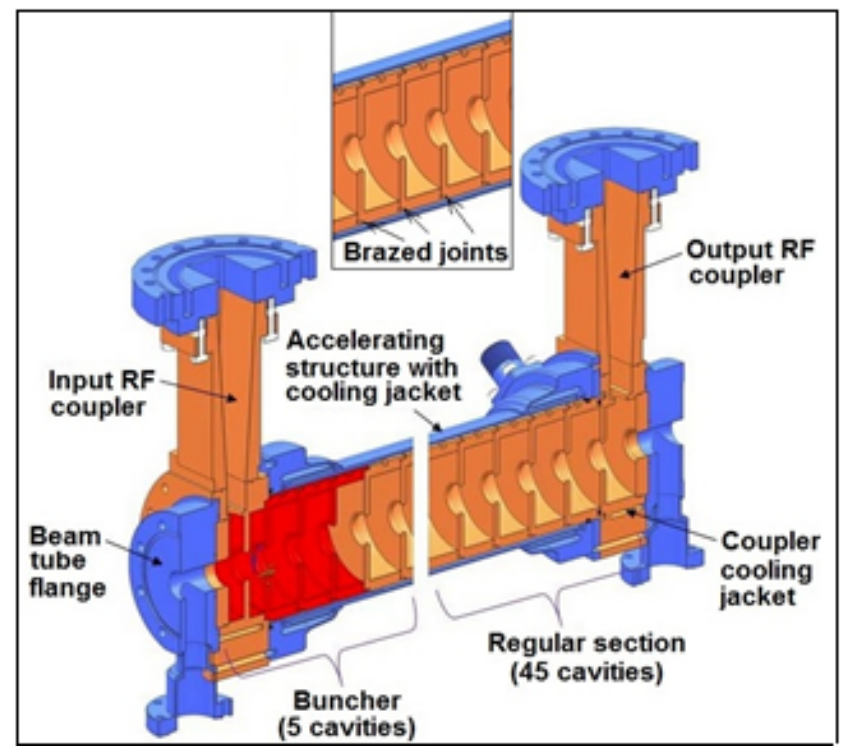

Figure 1. Schematic illustration of longitudinal section of accelerating structure. Brazed joints are shown in the inset.

Hence, present experimental investigation was undertaken with an objective to investigate corrosion possibilities in the cooling circuit which can be one of the life limiting factors of the accelerating structures.

\section{Experimental Details}

\subsection{Specimen Preparation}

The representative specimens for the experimental study were prepared by vacuum brazing an OFE copper assembly 
with matching joint configurations. The assembly was brazed in a vacuum furnace at a pressure of $5 \times 10^{-6} \mathrm{mbar}$. The BFM used for brazing was $1.0 \mathrm{~mm}$ diameter wire of $\mathrm{Ag}-\mathrm{Cu}$ eutectic, BVAg-8 of AWS A5.8 [3] (composition: $72 \mathrm{Ag} / 28 \mathrm{Cu} ; \mathrm{T}_{\mathrm{M}}=1052 \mathrm{~K}$ ). The thermal cycle used for brazing was: Heating rate $\sim 3 \mathrm{~K} / \mathrm{min}$, Soaking at $1023 \mathrm{~K}$ and final temperature of $1073 \mathrm{~K}$ for 5 minutes. The specimens were cut from the brazed assembly in such a way to expose the brazed joint. Figure 2 presents top and side views of one of the brazed specimens used for the study. In addition, a "braze filler" specimen was also prepared by casting BFM in a cylindrical groove machined $(\mathrm{dia}=13 \mathrm{~mm}$; depth $=3 \mathrm{~mm})$ in a $10 \mathrm{~mm}$ thick OFE copper plate. The procedure adopted for preparation of this specimen involved filling of machined grooves with small cut pieces of BFM wire and subjecting it to vacuum brazing cycle. During the process of casting, the machined grove was covered to minimize loss of silver. The top surface of as cast specimen was subsequently machined to obtain flat surface (as shown in Fig.3) for subsequent corrosion testing. In the forthcoming part of the report this specimen is referred as "BVAg8 braze filler".

Vacuum brazed copper specimens were subsequently characterized by microstructural examination by scanning electron microscopy (SEM) and energy dispersive spectroscopy (EDS), potentio-dynamic polarization testing, immersion testing and X-ray diffraction (XRD).

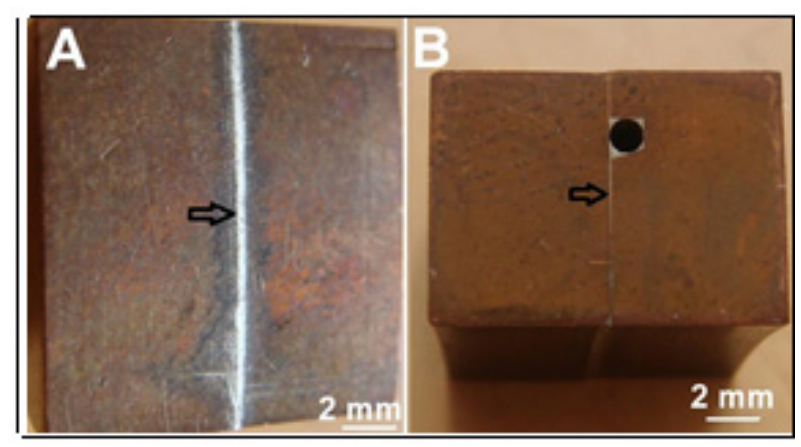

Figure 2. (A) Top and (B) side views of brazed specimen. Cavity seen in (B) was meant for filler wire placement. Arrows mark brazed joint.

\subsection{Specimen Characterization}

Corrosion experiments were performed in two sets viz. (i) potentio-dynamic polarization tests in process water and (ii) immersion testing in stagnant and flowing process water. The potentio-dynamic polarization tests were performed on OFE copper, brazed OFE copper and "BVAg8 braze filler" specimens. The specimens used for potentio-dynamic polarization tests were embedded in a cold-setting resin in such a way to expose the desired surface. Before specimen mounting, an electrical connection was provided to the specimen by spot welding a metallic wire to the back of the specimen. The surface to be investigated was metallographically ground and polished. All the edges of the polished specimens were masked with a lacquer to avoid any crevice attack during the test. The tests were performed in an electro-chemical cell, comprising of a three-electrode system viz. reference electrode (saturated $\mathrm{Ag} / \mathrm{AgCl}$ ), counter electrode (platinum) and working electrode (specimen). Polarization tests were carried out in deaerated process water, achieved by purging with nitrogen gas. The tests involved sweeping potential from $-0.5 \mathrm{~V}$ to $1.5 \mathrm{~V}$ at the rate of 10 $\mathrm{mV} / \mathrm{min}$, while simultaneously recording resultant current.

The experimental set up used for immersion testing of brazed specimens in flowing process water comprised of a glass beaker whose inlet was connected to a small submersible pump placed inside a container filled with process water. The outlet of the glass beaker was flown back to the container to form a closed flow loop circuit. During course of the test, process water was circulated at the flow rate of about $940 \mathrm{ml} / \mathrm{min}$. with associated velocity of about $0.31 \mathrm{~m} / \mathrm{s}$. It should be noted that in order to simulate actual service condition of the component no efforts were made to control dissolved oxygen and $\mathrm{CO}_{2}$ during immersion testing. Figure 4 shows experimental set up for immersion testing of the specimens. Initial $\mathrm{pH}$ and conductivity of process water used immersion and polarization tests were 6.44 and $9.35 \mathrm{mS} / \mathrm{cm}$, respectively. The immersion test specimens were periodically removed from process water after 7, 25 and 45 days and examined for corrosion and film formation. Besides test specimens, $\mathrm{pH}$ and conductivity of process water were also measured at various stages of immersion testing.

Table 1. $\mathrm{pH}$ and conductivity of process water at different stages of immersion testing

\begin{tabular}{|c|c|c|c|c|}
\hline \multirow{2}{*}{} & \multicolumn{2}{|c|}{ Stagnant process water } & \multicolumn{2}{c|}{ Flowing water } \\
\cline { 2 - 5 } & $\mathrm{pH}$ & $\begin{array}{c}\text { Conductivity } \\
(\mu \mathrm{S} / \mathrm{cm})\end{array}$ & $\mathrm{pH}$ & $\begin{array}{c}\text { Conductivity }(\mu \\
\text { S/cm })\end{array}$ \\
\hline On day 0 & 6.44 & 9.35 & 6.44 & 9.35 \\
\hline 7 days & 6.93 & 10.71 & 6.99 & 10.72 \\
\hline 25 days & 6.45 & 35.2 & 7.11 & 100 \\
\hline 45 days & 6.94 & 33.3 & 7.34 & 124.4 \\
\hline
\end{tabular}

In order to identify surface layer formed on immersion-tested specimens were characterized by grazing angle X-ray diffraction (G-XRD), performed with $\mathrm{CuK}_{\alpha}$ characteristic radiation $\left(\lambda=1.54^{\circ} \mathrm{A}\right)$ at an angle of $1^{\circ}$. In addition, $\mathrm{pH}$ and conductivity of process water were also recorded at various stages of immersion testing.

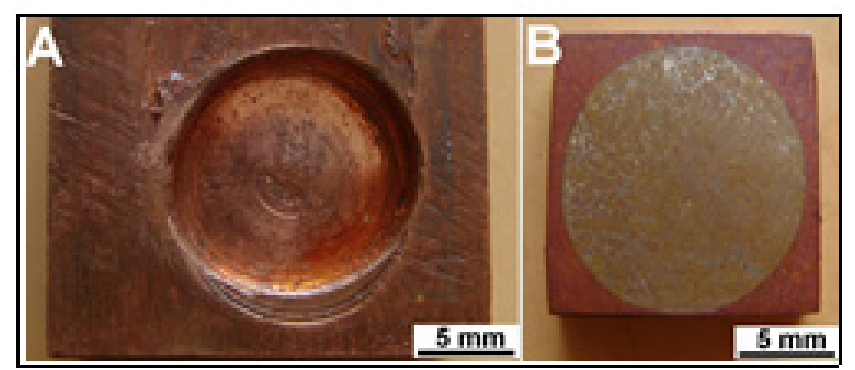

Figure 3. Preparation of "BVAg8 braze filler" specimen: (A) machined groove in a $\mathrm{Cu}$ block and (B) cast filler specimen after machining. 


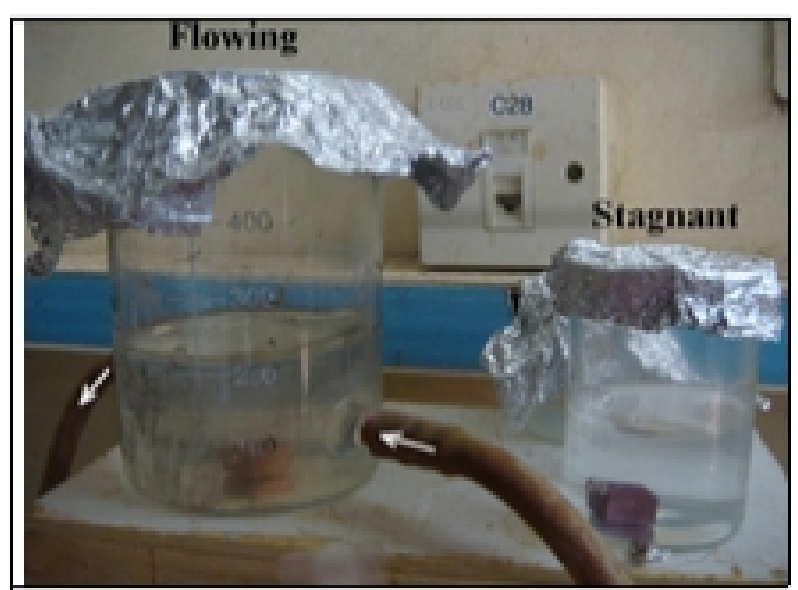

Figure 4. Immersion testing of specimens in flowing and stagnant conditions.

\section{Results and Discussion}

\subsection{Metallographic Examination of as Brazed Specimens}

Metallographic examination of brazed specimen, used for the experimental study, displayed typical duplex eutectic microstructure of the brazed joint. Bright and dark phases of braze microstructure were rich in $\mathrm{Ag}$ and $\mathrm{Cu}$, respectively. Copper/braze interface exhibited wavy profile with limited intergranular penetration of BFM into OFE copper substrates on both sides. Energy dispersive spectroscopic (EDS) analysis of the brazed specimen demonstrated presence of about $8 \mathrm{wt} \%$ silver in the copper part adjacent to the brazed joint. Figure 5 presents cross-section of OFE copper brazed joint and associated compositional profile. It is reported that during brazing of OFE copper, Cu-rich cells (with about 8\% $\mathrm{Ag}$ ) grow from the surface of copper part into the braze filler metal [4]. Silver content of the Cu-rich cells is determined by solubility limit of silver in copper at the brazing temperature of $1052 \mathrm{~K}$ (8 wt\% [5]). It may be noted that growth of $\mathrm{Cu}$-rich cells is accompanied by enrichment of the brazed joint with respect to $\mathrm{Ag}$. During the process, $\mathrm{Ag}$ tends to penetrate copper along its grain boundaries. Due to limited solubility of silver in copper, the growth of $(\mathrm{Cu}, \mathrm{Ag})$ phase is likely to be slower, although relatively faster diffusion of silver occurs along copper grain boundaries.

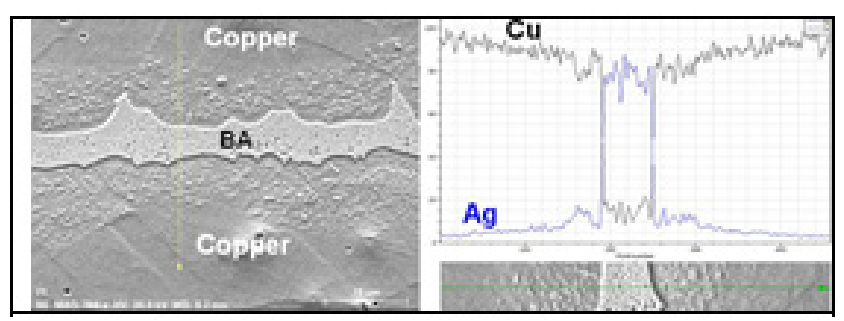

Figure 5. Microstructure and associated EDS composition profile across OFE copper brazed specimen.

\subsection{Potentio-dynamic Polarization Tests}

Potentio-dynamic polarization tests were performed on OFE copper, brazed OFE copper and "BVAg-8 braze filler" specimens. All these specimens displayed almost similar polarization behaviour, as shown in Fig. 6. These specimens exhibited spontaneous passivation with no trans-passive dissolution till $1.5 \mathrm{~V}$. Passive current density of the specimens at $0.75 \mathrm{~V}$ was found to be $\sim 10^{-5} \mathrm{~A} / \mathrm{cm}^{2}$. Table 2 presents values of $\mathrm{E}_{\text {corr }}, \mathrm{I}_{\text {corr }}$ and corrosion rate of the three tested specimens, as estimated from respective polarization plots. Largely similar value of $\mathrm{I}_{\text {corr }}$ for the three specimens is indicative of their similar corrosion rates in process water.

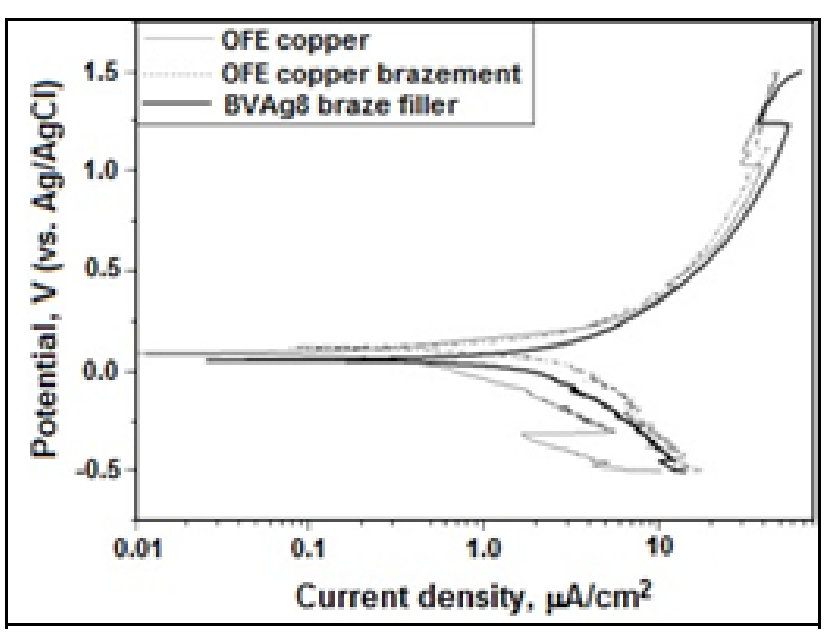

Figure 6. Polarization curves in $\mathrm{LCW}$ for OFE $\mathrm{Cu}$, OFE $\mathrm{Cu}$ brazement and BVAg8 braze filler.

Table 2. Results of potentio-dynamic polarization tests

\begin{tabular}{|c|c|c|c|}
\hline & $\mathrm{I}_{\text {corr }}\left(\mu \mathrm{A} / \mathrm{cm}^{2}\right)$ & $\mathrm{E}_{\text {corr }}(\mathrm{V})$ & $\begin{array}{c}\text { Corrosion Rate, } \\
\text { Mils per year (MPY) }\end{array}$ \\
\hline OFE copper & 1.29 & 0.059 & 0.59 \\
\hline $\begin{array}{c}\text { Brazed OFE } \\
\text { copper }\end{array}$ & 1.23 & 0.014 & 0.57 \\
\hline $\begin{array}{c}\text { BVAg8 braze } \\
\text { filler }\end{array}$ & 1.43 & 0.126 & 0.73 \\
\hline
\end{tabular}

Metallographic examination of potentio-dynamic polarization tested "BVAg8 braze filler" specimens exhibited etching contrast between silver-rich (light) and copper-rich (dark) phases of the eutectic microstructure. Similar etching contrast is seen in the brazed joint of brazed OFE copper specimen. On the other hand, single phase microstructure of OFE copper specimen displayed light etching contrast after polarization test. Figure 7 presents polarization-tested surfaces of brazed OFE copper, OFE copper, BVAg8 braze filler specimens. It is to be noted that relatively greater corrosion attack on $\mathrm{Cu}$-rich phase (with respect to Ag-rich phase) in BVAg8 braze filler as well as in the brazed joint is attributed to significantly more nature of silver with respect to copper in standard emf series [6]. 


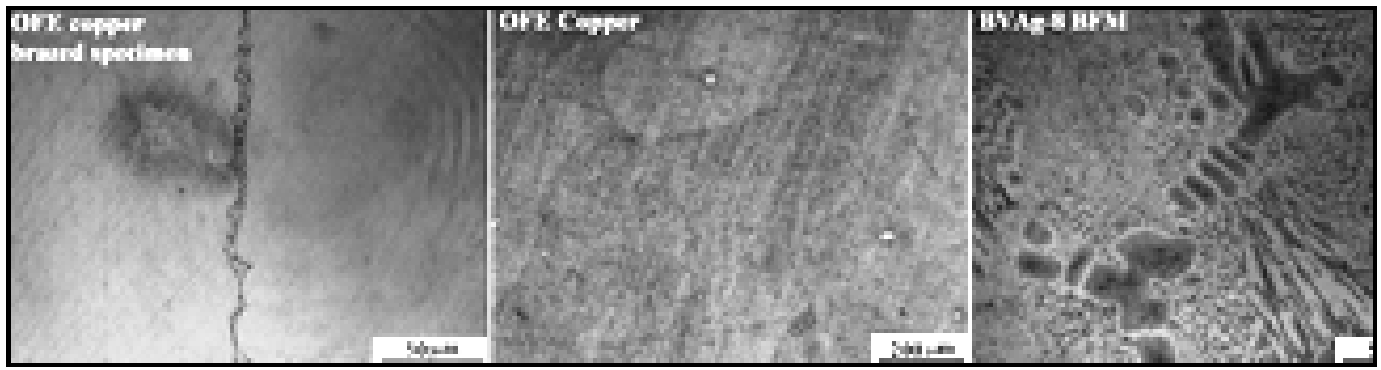

Figure 7. Polarization-tested surfaces of (i) brazed OFE copper, (ii) OFE copper and (iii) BVAg8 braze filler specimens.

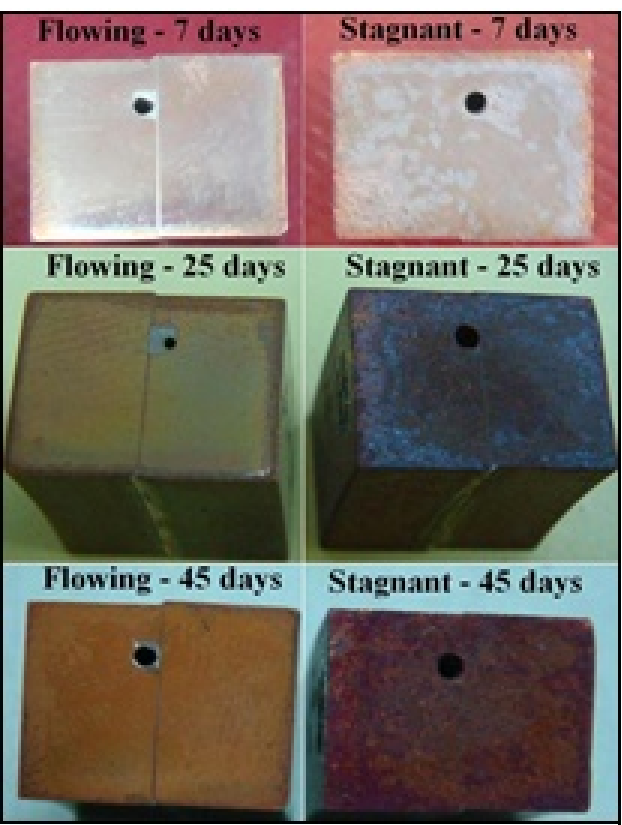

Figure 8. Appearance of brazed OFE copper specimens at various stages of immersion testing in flowing and stagnant process water.

\subsection{Immersion Tests}

An important visual observation of immersion-tested specimens was the stark difference in the appearance of specimens exposed to stagnant and flowing process water. In contrast to presence of dark adherent surface film on brazed copper specimens exposed to stagnant process water, the surface of specimen tested in flowing condition remained much brighter, even after 45 days of its exposure. Under stagnant condition, formation of surface film was noticed within 7 days of specimen's exposure. Figure 8 compares visual appearance of immersion-tested brazed specimens (in stagnant and flowing process water) after 7, 25 and 45 days of their exposure. Copper, when exposed to neutral or slightly alkaline water, is known to develop a protective oxide layer. This protective layer comprises of cuprous species with other copper products like cupric oxide, cupric hydroxide and possibly cupric carbonate [7]. Grazing angle XRD performed on OFE copper as well as "BVAg-8 braze filler" specimens, exposed to stagnant process water, demonstrated that the surface film was comprised of $\mathrm{Cu}_{2} \mathrm{O}$ and $\mathrm{CuO}$, as shown in Fig. 9.

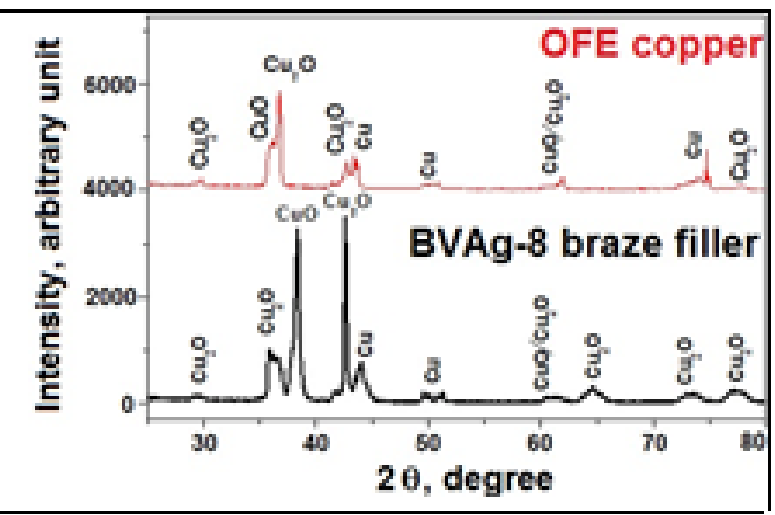

Figure 9. Grazing angle X-ray diffraction (G-XRD) showing surface film composed of $\mathrm{Cu}_{2} \mathrm{O}$ and $\mathrm{CuO}$ in stagnant condition.

Analysis of process water used for immersion testing exhibited minor change in its $\mathrm{pH}$ value for both stagnant and flowing test conditions. On the other hand, larger increase in conductivity of process water was noticed with the progress of immersion testing. Table 1 summarizes $\mathrm{pH}$ and conductivity of process water parameters at different stages of immersion testing under "stagnant" and "flowing" conditions. It should be noted that the difference in the conductivity of process water used in "stagnant" and "flowing" conditions was quite low till 7 days of testing. However, with further exposure the conductivity of process water used in "flowing condition" recorded much larger increase with respect to its counterpart used in "stagnant condition. Possible contributing factors for the increase in water conductivity are believed to be increase in dissolved oxygen and carbon dioxide content and release of copper species from the oxides $[7,8]$.

Metallographic examination of brazed OFE copper specimens, immersion tested in flowing process water, revealed that Ag-alloyed zone adjacent to the brazed joint (refer Fig. 5) experienced relatively greater corrosion with respect to brazed joint. The above effect was reflected in the form darkly etched bands adjacent to the brazed joint. Figure 10 presents magnified view of the cross-section of brazed OFE copper specimens at different stages of immersion testing under flowing process water. On the other hand, no such banded feature was observed in the specimen tested in stagnant condition, as shown in the Fig.11.

Weight loss analysis performed after 45 days of immersion testing of brazed OFE copper specimens in 
flowing water condition revealed a general corrosion rate of $4.5 \mathrm{~mm} /$ year (equivalent to $0.18 \mathrm{mils} / \mathrm{year}$ ) while similar specimen in stagnant process water displayed weight gain due to surface film formation.

The results of the study have demonstrated that under stagnant process water, exposed surface of OFE copper as well as BVAg8 braze filler specimens get easily passivated, as seen in the polarization tests. Immersion tests have also demonstrated formation of adherent dark-coloured passive oxide film on the surface of brazed specimen which prevents further corrosion of underlying copper/brazed joint. Rios et al have also reported that under stagnant condition film formation on copper substrate takes place in the initial hours of its immersion. An increase in the thickness of oxide film thickness is associated with corresponding increase in its polarization which hinders diffusion of copper species across the oxide layer resulting in reduced corrosion rate [7]. On the other hand, immersion testing of copper specimens under flowing process water resulted in significantly reduced thickness of oxide film which should yield smaller polarization resistance and therefore relatively higher corrosion rate [7], which was reflected in larger rise in the conductivity of process water. It has been reported that corrosion of copper in water (with dissolved oxygen content) proceeds under cathodic diffusion control and as a result an increase in agitation or flow velocity causes corresponding increase in corrosion rate [4]. The rate of general corrosion, as estimated from short term immersion tests in flowing conditions, remains quite low (0.18 mils/year), in spite of relatively higher conductivity of process water (with respect to that specified value of $<1 \mathrm{mS} / \mathrm{cm}$ ) used. A long term study (for more than 30 years) performed by Glesener et al. [2] on SLAC brazed joints (made with Au-Cu BFM) reported an estimated corrosion rate of about 1 mils/year

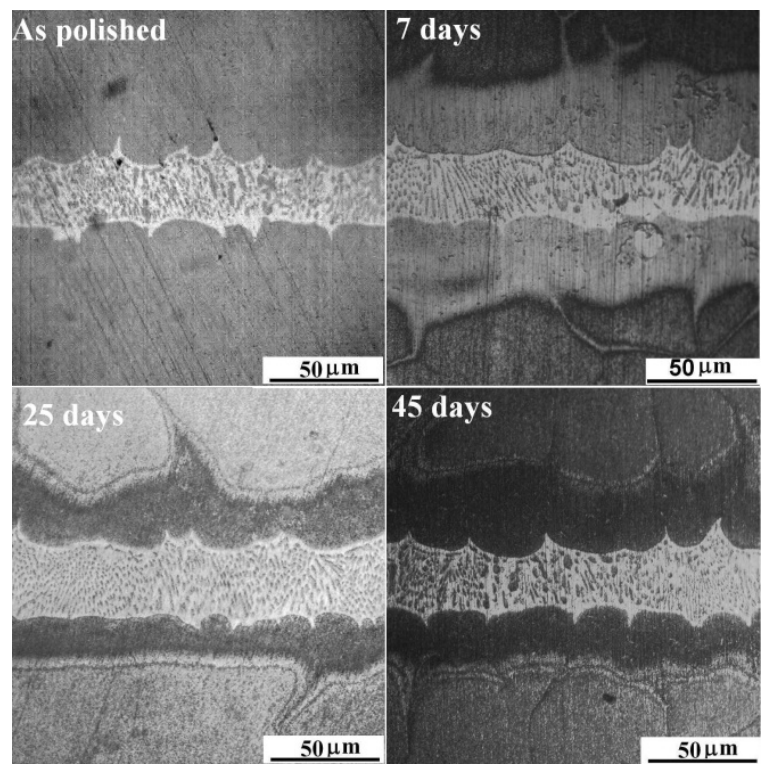

Figure 10. Surface of brazed OFE copper specimen at various stages of immersion testing in flowing process water

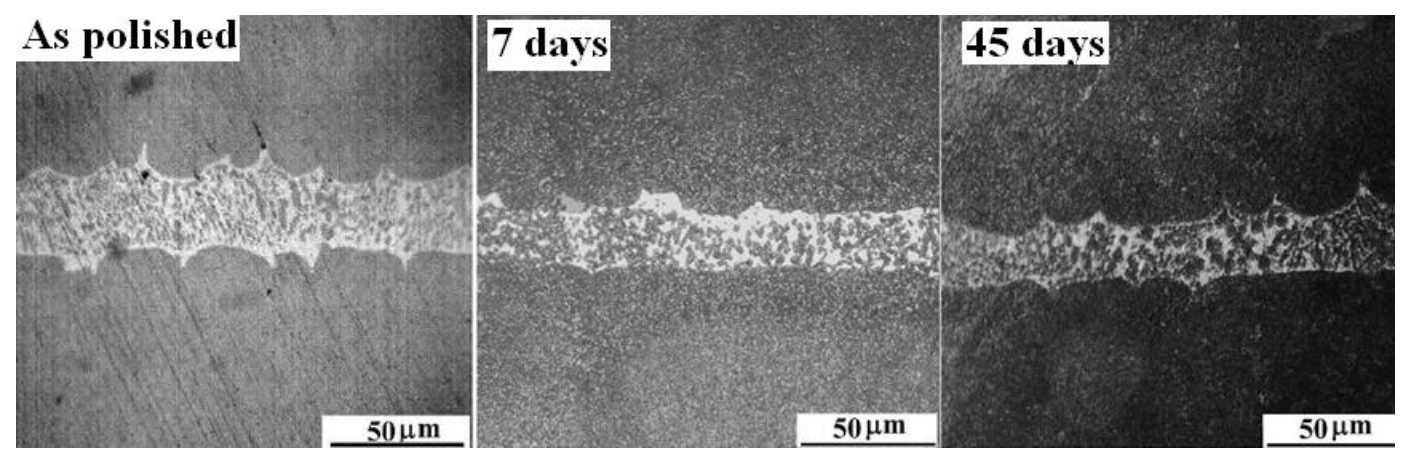

Figure 11. The surface of brazed OFE copper specimen at various stages of immersion testing in stagnant process water. 


\section{Conclusions}

On the basis of the results of the experimental study, following inferences are drawn:

1. Metallographic examination of brazed specimen displayed typical duplex eutectic microstructure of the brazed joint. Bright and dark phases of braze microstructure were rich in $\mathrm{Ag}$ and $\mathrm{Cu}$, respectively. Copper/braze interface exhibited wavy profile with limited intergranular penetration of BFM into OFE copper.

2. Brazed OFE copper specimens exposed to stagnant process water develops a dark and adherent oxide film on its surface. This surface oxide film, which grows in thickness with increased exposure, protects underlying substrate from further corrosion.

3. In the case of flowing process condition, oxide film on the exposed surface of the specimens remains quite thin and the specimen experiences relatively higher corrosion rate.

4. In the brazed joint, corrosion attack was relatively more pronounced on $\mathrm{Cu}$-rich phase (with respect to Ag-rich phase) which is attributed to more noble character of silver with respect to copper.

5. On the basis of 45-day long immersion test in flowing process water, general rate of corrosion of brazed OFE copper specimen was estimated to be about 0.18 mils/year (or $4.5 \mathrm{~mm} /$ year) which is quite low.

6. A long-term corrosion study in simulated process loop would provide more useful information regarding corrosion behaviour of the brazed joints of the accelerating structure.

\section{Acknowledgements}

Authors thankfully acknowledge technical assistance of Shri Ram Nihal Ram in metallographic specimen preparation.

\section{REFERENCES}

[1] Nita S Kulkarni and Vinit Kumar, Electromagnetic design of $10 \mathrm{MeV}, 6 \mathrm{~kW}$ electron linear accelerator for industrial applications, RRCAT internal report No. RRCAT/2014-03.

[2] W. F. Glesnener and E. L. Garwin, Projected life of the SLAC Linac Braze Joints: Braze Integrity and corrosion of cooling water hardware on accelerator section. Proc. SLAC-TN-06-0006, 2006.

[3] AWS A5.8M/A5.8:2011-AMD1. 2013. Specification for Filler Metals for Brazing and Braze Welding, 10th edition, American Welding Society.

[4] W. D. Zhuang and T. W. Eagar, Diffusional breakdown of nickel protective coatings on copper substrate in silver-copper eutectic melts, Metallurgical and Materials Transactions A, 28, 1997, 969-977.

[5] ASM Handbook: Volume 3: Alloy Phase Diagrams, 10th ed. ASM International, Materials Park, OH, 1992.

[6] M. G. Fontana, Corrosion Engineering, 3rd ed., McGraw-Hill, 1989.

[7] J. F. Rios, J. A. Calderón, and R. P. Nogueira, Electrochemical Behavior of Copper in Drinking Water: Evaluation of Dissolution Process at Low Anodic Overpotential, J. Braz. Chem. Soc., 22(7), 2011, 1362-1370, .

[8] R. Dortwegt, Low-Conductivity Water Systems for Accelerators, Proc. IEEE Particle Accelerator Conf., 2003. 